\title{
EVALUATION OF SOME PLANT EXTRACTS AND CHEMICAL PESTICIDES ON GARLIC THRIPS THRIPS TABACI AND ASSOCIATED VEGETATIVE GROWTH PARAMETERS IN GARLIC FIELDS
}

\author{
AFAF M.S. EL- ROBY \\ * Plant Protection Research Institute, ARC, Dokki, Giza, Egypt. \\ (Manuscript received 10 December 2017)
}

\begin{abstract}
$\mathrm{T}$ his study was conducted in Abuqurqas district Minia Governorate during in Egypt throughout 2015- 2016 garlic season to study the effect of some chemical and plant extract pesticides in controlling the thrips garlic Thrips tabaci((Thysanoptera: Thripidae) . The insecticide confidor was sprayed three times. Result showed highly significant effect at intervals (1days, 3days, 7days and 10 days). While, the other insecticides were low significantly effective against the pest as compared to control. In addition, higher values of vegetative growth parameters were obtained when plants received Confider, Selecron and Decis respectively. The lowest values of fresh weight were recorded after most of treatments and were insignificantly compared with control.
\end{abstract}

\section{INTRODUCTION}

Garlic is the most important export crops desired in European markets and other countries in the world (Hazara et al., 1999), due to its quality and good carry it for storage, as well as his appearance at a time when demand and severe need of markets too big to be, and so the prices, making it a profitable crop with a farm.. The garlic thrips T. tabaci is one of the main insect pests attacking onion plants during their different stages and caused a great damage, which resulted to reduction in the crop yield, (Eltez and Karasavuran 2006 and Mahmoud 2008).

Features from the rest of the garlic crop that grows in climatic regions of the world, but there are distinct regions of growth such as Egypt, Spain and the United States and Japan. Consumption of garlic has been increasing significantly in the world partly because of the health benefits they possess [Abdou, et al, 2004]. Onion thrips, Thrips tabaci L. (Thysanoptera: Thripidae) is polyphagous and have been recorded on more than 300 species of plants [Abdou et al., 2004]. It is a major insect pest in most onion growing areas of Ethiopia. Anon [Badran, and Safwat, 2004] found that large number of thrips kill onion seedlings, while damage to older plants by thrips may cause crops to mature early and, subsequently reduce yields. Adult and nymph stages (immature) of thrips feed by rasping the leaves and other tissues of plants to release the sap, which they then consume with a punch and suck behavior that removes leaf chlorophyll 
causing white to silver patches and streaks. The injury caused by thrips rasping of the leaves enables various plant pathogens to gain entry, thus increasing disease problems. In addition, thrips carry plant pathogens on their mouthparts from one plant to another. In onions, entire fields can be destroyed, especially in dry seasons. Studies indicate several attempts to combat the pest thrips in general on families' using many different ancient and modern pesticides, natural and artificial. In addition, it was noted that the fight against garlic Terps on cotton, has led to the protection of seedlings and improve their appearance, but they did not lead to increased production (Newson et al, (1953). Warriach et al. (1997) studied the effect of Rogor (dimethoate) on T. tabaci in onions field also.

Aim of the research: - This study was designed to evaluate of some chemical and bio-pesticides in the garlic fields against the garlic thrips to determine the percentage reduction of T.tabaci number. In addition to determine the effect of the suggested treatments on the vegetative growth of garlic plants.

\section{MATERIALS AND METHODS}

This field experiment were conducted at the (Abuqurqas), Minia Governorate ,throughout the end of 2015and the beginning of 2016 garlic season (mid-September), in order to test the efficiency of some chemical and plant extracts on the population density of thrips garlic Thrips tabaci and their associated vegetative growth parameters of garlic plants .

An area of about $700 \mathrm{~m}^{2}$ (4 karates) was divided into six equal plots, each plot contain three replicates. All normal agricultural practices of land preparation, thinning, irrigation, mechanical weed control followed. Each of the following materials were applied on three replicates / treatment.

1- Confider 70 WG (Foliar spray) on shoots

2- Selecron 320 EC (Brofenofos $320 \mathrm{~g} / \mathrm{L}$ ).

3- Decis50g/L 50 EC (Deltamethrin).

4- dried Pumpkin leaves in methanol extract.

5- Masrona oil (Summer Oil (Delta) 24 liters / Fadan).

6- Control (untreated plants).

Preparing of Pumpkin extract Fifty grams, as mentioned by (Edeoga et al. (2006). Dried sample were extracted by methanol at ratio of $1 \mathrm{gm}$. powder: 2-cm. solvent in high speed for 15 minutes then filtered. Solvents were evaporated until dryness to obtain the crude extract. A volume of $500 \mathrm{~cm}^{3}$ of water were mixed with the residue of dried extract. Application of the assayed materials took place by using one-liter hand sprayer. 10 days after spraying insects were counted. A sample of 10 leaves and labs / 
treatment randomly selected. The counts were made by direct examine both leaf surfaces.

Spraying of each materials applied at three times as follows:-

1- $1^{\text {st }}$ spray (last week of March).

2- $2^{\text {nd }}$ spray (First week of April).

3- $3^{\text {rd }}$ spray (last week of April).

Harvest yield parameters were recorded after for each treatments: - plant fresh

weight. Plant height, leaves number, leaves fresh weight, and bulbs fresh.

\section{Statically analysis: -}

Data subjected to statically analysis SAS 9-3.1 to determine the significance between means of the tested treatments. And so on LSD. Was applied. Well as less moral test teams $1 \%$ Confidence level and $5 \%$. As for other pesticides, the efficiency of each pesticide was calculated for each individual replicates Using the Henderson-Tilton's formula (1955):

$\mathrm{n}$ in Co before treatment $\times \mathrm{n}$ in T after treatment

Corrected $\%=(1$ )$\times 100$

$\mathrm{n}$ in Co after treatment $\times \mathrm{n}$ in $\mathrm{T}$ before treatment

Where: $\mathrm{n}=$ Insect population, $\mathrm{T}=$ treated, $\mathrm{Co}=$ control

\section{RESULTS AND DISCUSSION}

A-Effect of treatments against T.tabaci .

A.1. After $1^{\text {st }}$ spray:-

Table 1. Effect of some chemical and plant extracts pesticides on population density of trhrips after the first spray.

\begin{tabular}{|l|c|r|r|r|c|}
\hline \multirow{2}{*}{\multicolumn{2}{c|}{ Treatment }} & \multirow{2}{*}{ Pre } & \multicolumn{4}{c|}{ Mean number of thrips/ plant after the } \\
\cline { 3 - 6 } & & \multicolumn{1}{c|}{ f day } & 3 day & 7 day & 10 day \\
\hline 1- Confidor70wG & 34.00 & 12.33 & 10.33 & 32.00 & 27.66 \\
\hline 2-Selecron & 44.33 & 30.33 & 20.33 & 52.33 & 33.66 \\
\hline 3-Decis 50 EC & 50.00 & 33.66 & 34.33 & 56.33 & 40.00 \\
\hline 4- Pumpkin Methanol extract & 60.67 & 40.33 & 36.66 & 63.00 & 46.66 \\
\hline 5-Masroana oil & 52.67 & 41.33 & 45.00 & 69.33 & 58.66 \\
\hline 6-control & 63.00 & 48.00 & 50.33 & 92.00 & 74.33 \\
\hline
\end{tabular}

F. value $=7.58 \quad$ and $\quad$ L.S.D $=11.07 \%$.

Data presented in Table (1) clearly indicated that, the untreated garlic plant had significantly the highest mean numbers of thrips after different intervals periods ( 1 , 3,7 and 10 days) from the first spray had (48.00, 50.33, 92.00 and 74.33 thrips/plant) respectively. While, Confidor treatment caused the highest efficacy and the lowest mean 
number of thrips / plant $(12.33,10.33,32.00$, and 27.66 , respectively. Followed by the chemical insecticides selecron (33.66), Decis (40.0) and the planet Pumpkin Methanol extract (46.66) 10 days after the first spray, respectively. On the converse, lowest efficacy against thrips / plant, at the tested intervals (1, 3, 7 and after 10 days) after the first spray caused by masrona oil $(41.33,45,69.33$ and 58.66 thrips respectively.

\section{A.2. After $2^{\text {nd }}$ spray:-}

Table 2. Effect of some chemical and plant extracts pesticides on Population density of thrips after the second spray

\begin{tabular}{|l|l|l|l|l|l|}
\hline \multirow{2}{*}{ Treatment } & \multirow{2}{*}{ Pre } & \multicolumn{4}{l}{$\begin{array}{l}\text { Mean number of thrips/plant } \\
\text { after the second spray }\end{array}$} \\
\cline { 3 - 7 } & & 1day & 3 day & 7 day & 10 day \\
\hline 1-Confider 70 WG & 72.67 & 9.30 & 15.00 & 22.00 & 16.66 \\
\hline 2-Selecron & 59.33 & 31.33 & 21.66 & 37.66 & 25.33 \\
\hline 3-Decis 50 EC & 66.67 & 33.66 & 24.33 & 46.66 & 30.33 \\
\hline 4- Pumpkin Methanol extract & 72.33 & 38.66 & 35.33 & 51.66 & 41.00 \\
\hline 5-Masrona oil & 61.00 & 59.00 & 49.33 & 76.00 & 72.33 \\
\hline 6-Control & 75.00 & 86.00 & 58.00 & 99.00 & 88.66 \\
\hline \multicolumn{5}{|}{ and } & \multicolumn{5}{c}{ L.S.D. $=16.063$} & \\
\hline
\end{tabular}

Data in Table (2) manifested that the maximum population density of thrips were occurred after 10 days from the second spray, 88.66 thrips on untreated garlic plants. While the minimum population (mean number of thrips / plant) in plots treated with confider (16.66), followed by selecron (25.33), Decies (30.33) and Pumpkin Methanol extract (41.00).The least efficiency material recorded for Masroana oil (72.33). All treatments were significantly than control.

\section{A. 3. After $3^{\text {rd }}$ spray:-}

Table 3.Effect of some chemical pesticides and plant extracts on population density of thrips after the third spray

\begin{tabular}{|c|c|c|c|c|c|}
\hline \multirow{2}{*}{ Treatment } & \multirow{2}{*}{ Pre } & \multicolumn{4}{|c|}{$\begin{array}{l}\text { Mean number of thrips/plant } \\
\text { after the third spray }\end{array}$} \\
\hline & & 1day & 3 day & 7 day & 10 day \\
\hline 1-Confider 70 WG & 38.33 & 6.66 & 15.66 & 9.00 & 7.00 \\
\hline 2-Selecron & 48.00 & 11.00 & 20.00 & 16.33 & 9.33 \\
\hline 3-Decis 50 EC & 44.33 & 20.33 & 30.66 & 20.66 & 15.66 \\
\hline 4- Pumpkin Methanol extract & 42.67 & 22.33 & 34.66 & 22.33 & 18.33 \\
\hline 5-Masrona oil & 40.33 & 30.33 & 37.33 & 28.33 & 20.66 \\
\hline 6-Control & 52.00 & 42.33 & 42.00 & 33.66 & 31.00 \\
\hline
\end{tabular}


As occurred concerning the effect of treatments on the mean number of thrips after the first and the second spray, these treatments caused significant efficacy against the thrips and tabaci than control.

As shown in table (3) among the untreated garlic plants after the $3^{\text {rd }}$ spray the mean number of thrips were $42.33,42.00,33.66$ and 31.00 thrips / plant after $1,3,7$, and 10 days, respectively. The highest effective treatment in reducing the mean number of thrips was confider treatment of that only $6.66,15.66,9.00$ and 7.00 thrips / plant after the $3^{\text {rd }}$ spray for $1,3,7$, and 10 days, respectively.

The other treatments, 4 materials could be arranged descendible according to their efficacies in reducing the mean number of thrips after 10 days from $3^{\text {rd }}$ spray as selecron (7.00 thrips / plant), Decies (15.66), Pumpkin that extract (18.33) and Masrona oil (20.66) respectively in (Table 3 ).

From the previous results, showed that the population density of thrips, it is clear in all the three sprays, confider was more effective than other insecticide followed by Selecron, Desice and Pumpkin Methanol extract, while the least efficient was Masroana oil leading to the highest number of thrips on Garlic plants.

These results are in harmony with (Gengotti, Ceredi and Censi. 2002), Also Genotti and Censi (2003), who mentioned that the pesticide did not have a significant effect on onion thrips in reducing the effect of the pest.

\section{B-Effect of treatments on vegetative growth parameters}

Data presented in Table (4) clearly indicated that, the vegetative, growth parameters of garlic plants expressed as plant height, leaves number and Neck length had significantly effect by chemical and plant extract pesticides treatments. The highest value of plant height as vegetative growth parameters were obtained when garlic plants received selecron treatment, which achieved mean $(35.33 \mathrm{~cm} . /$ plant). That was, significantly followed by Confidor , Decis and Pumpkin extract, as means 34.66, 34.66 and 33.66 , respectively, while, the untreated plants achieved mean as $20.33 \mathrm{~cm}$. In other parameters, among the untreated garlic plants, the leaves number 1.39 leaves as mean plant (after 60 and 75 days of sowing). This value was significantly higher than those recorded from all the 6 treatments. The highest number of leaves detected among garlic plants sprayed by Confidor (mean of 2.77 Leaves/plant.) Gadallah, F. M. and T. A. ElMasry, 2006. In addition, the efficacy of the other treatments on the vegetative growth parameters were low significantly means by Selecron, Decies, Pumpkin extract and Masrona oil being $(2.53,2.22,2.19$ and 2.11) respectively. Comparing with control which recorded the lowest leave numbers 1.39 leaves / plant, those obtained by1Abou El-Magd et al 2010. As shown in Table (4), among the untreated garlic plants, the third 
parameter of vegetative growth Neck length, the higher length Neck were obtained when garlic plant received Decis , Confider and Selecron compounds treatments being $8.36,8.34$ and $8.31 \mathrm{~cm} /$ plant ,respectively. In comparison, the lowest values of plant height, leaves number and Neck length as well as fresh weight total of leaves, necks and bulbs was recorded by Pumpkin methanol extract and Masrona oil. Results revealed that Confider, Selecron and Decis enhanced the vegetative growth of garlic plants.Many investigators come to similar result; Farman2010, Razzaq 2003 and RAO 1986 Who reported that chemical pesticide or Thiodan, Confidor, were significantly greater than those of the control, very effective in reducing the incidence of $T$. tabacion onion.

Table 4.-Efficiently of some plant extract and chemical pesticides on vegetative growth parameters of garlic plant.

\begin{tabular}{|c|c|c|c|c|c|c|c|}
\hline \multirow[t]{2}{*}{ Treatment } & \multirow{2}{*}{$\left|\begin{array}{c}\text { Plant height } \\
(\mathrm{cm})\end{array}\right|$} & \multirow{2}{*}{$\begin{array}{c}\text { Leaves No.l } \\
\text { plant }\end{array}$} & \multirow{2}{*}{$\begin{array}{l}\text { Neck } \\
\text { length } \\
(\mathrm{cm})\end{array}$} & \multicolumn{3}{|c|}{ Fresh weight (g/plant) } & \multirow[t]{2}{*}{ Total } \\
\hline & & & & Leaves & Neck & Bulbs & \\
\hline 1-Confidor & $34.66 a b$ & $2.77 \mathrm{a}$ & $8.34 \mathrm{a}$ & 6.16 & 4.66 & 33.97 & 44.79 \\
\hline 2-Selecron & $35.33 \quad \mathrm{a}$ & $2.53 \mathrm{ab}$ & $\begin{array}{|ll|}8.31 & \mathrm{a}\end{array}$ & 5.69 & 4.94 & 33.00 & 43.63 \\
\hline 3-Decis & $34.66 \mathrm{ab}$ & $2.22 \mathrm{ab}$ & $8.36 \mathrm{a}$ & 5.53 & 4.33 & 31.52 & 41.38 \\
\hline 4-Pumpkin Meth. Extract & $33.00 \mathrm{ab}$ & $2.11 \mathrm{ab}$ & $6.52 \mathrm{ab}$ & 5.13 & 3.61 & 30.98 & 39.72 \\
\hline 5-Masroana oil & $32.00 \mathrm{ab}$ & $2.19 \mathrm{ab}$ & $7.35 \mathrm{ab}$ & 5.50 & 3.54 & 28.51 & 37.55 \\
\hline 6-control & $20.33 \mathrm{~b}$ & $1.39 \mathrm{~b}$ & $5.33 \mathrm{~b}$ & 3.66 & 2.92 & 20.67 & 27.25 \\
\hline \begin{tabular}{|l|}
$F$ \\
\end{tabular} & 1.38 & 1.11 & 2.41 r & n.s & n.s & n.s & n.s \\
\hline L.S.D & 14.81 & 1.37 & $2.46 \mid$ & n.s & ns & n.s & n.s \\
\hline
\end{tabular}

\section{REFERENCES}

1. Abdou, M. A. H., A. A. El-Sayed; F. S. Badran and R. M. S. El-Deen, 2004. Effect of planting density and chemical and bio-fertilization on vegetative growth, yield and chemical compostion of fennel (Foeniculum vulgare. Miller): II. Effect of NPK chemical fertilization and bio- fertilization treatments.Ann. Agric, Sci. Moshtohor, 42(4):1923-1937.

2. Abou El-Magd, M. M., 1M. F. Zaki, 2S. A. Abo Sedera and 1T. T. El-Shorbagy 2014. Evaluation of Five Garlic (Allium Sativum L.) Cultivars under Bio-chemical and Mineral Fertilization, Middle East Journal of Agriculture Research, 3(4): 926-935, 2014 ISSN 2077-4605.J.Agric.Res.

3. Badran, F. S. and M. S. Safwat, 2004. Response of fennel plants to organic manure and bio-fertilizers in replacement of chemical fertilization. Egyptian J.Agric. Res. 82: (2 special Issue) 247-256.

4. Eltez, S.; and Y. Karasavuran (2006). Studies in the determination of population fluctuation of Thrips tabaci Lindeman [Thysanoptera: Thripidae] in processing tomato production areas areas in Izmir province, Turkey. Ege- 
5. Edeoga H. O., G. Omosun and L.C. Uche (2006). Chemical composition of Hyptis suaveolens and Ocimum gratissimum hybrids from Nigeria. African J. Biotechnol. Vol. 5 (10), pp. 892-895.

6. Farman Ullah, Maraj-ul-Mulk, Abid Farid, Muhammad Qasid Saeed and Shahid Sattar Farman et al 2010 Population Dynamics and Chemical Control of Onion Thrips (Thrips tabaci, Lindemann) Pakistan J. Zool., vol. 42(4), pp. 401-406, 2010.

7. Gadallah, F. M. and T. A. El-Masry, 2006. Onion growth and yield as affected by biofertilization. Ann. Agric. Sci. Moshtohor, 44: 987-1005.

8. Gomaa, M. G. M., 2006. Genetic studies on some economic characters in onion (Allium cepa. L.) Ph. D. thesis,Fac. Agric. El-Minia, Egypt.

9. Gengotti, S., G. Ceredi and D. Censi. 2002. Natural and synthetic insecticides against thrips on strawberry in Emilia - Romagna Fragaria x ananassa Duch. Atti - delle Giornate - Fitopatologiche (Italy) (pt.1) p. 463

10. - Genotti, S. and D. Censi. 2003. Evaluation of different active ingredients and application strategies against onion thrips in Emilia - Romagna (Italy) (Allium cepa L). Informatore - Fitopatologico (Italy) V. 53 (7-8) p. 44-48.

11. HAZARA, A.H., SHAKEEL, M., KHAN, J., IQBAL, M. AND KHAN, S., 1999. Effect of non-chemical methods and botanical insecticides on onion thrips, Thrips tabaci, Lind (Thysanoptera: Thripdae) in onion crop in Balochistan. Sarhad J. Agric., 15: 619624.

12. Henderson, C.F. and E. W. Tilton, 1955. Tests with acaricides against the brow wheat mite, J. Econ. Entomol. 48:157-161.

13. RAO, P.V.S. AND SWAMI, T.A.K., 1986. A note on the control of onion thrips tabaci. J. Pestic., 14:25- 26.

14. RAZZAQ, M., ASLAM, M., IQBAL, M., HUSSAIN, M. AND SHEHZAD, A., 2003. Efficacy of six insecticides with different mode of action against sucking pests of cotton. Sarhad J. Agric., 19: 97-99.

15. Mahmoud, H.H.(2008).Ecological Studies on certain insect pests of onion withspecial emphasis on the onion bulb fly Eumerus anoenus Loew. Ph.D.

16. Newsom, L.D.; J.S. Roussel and C. E. smith. 1953. The tobacco Thrips, its seasonal history and status as a cotton pest. Lousiana. Agri. Exp. Sta. Tech.

17. Weissling, T. J.; T. M. Lewis; L. M. McDonough, and D.R. Horton. 1997. Reduction in pear psylla (Homoptera: psyllidae) oviposition and feeding by foliar application of various materials. Canadian Entomol. 129 (4); 637 - 643 


\title{
تقييم بعض المبيدات الكيميائية والمستخلصات النباتية
} على تربس الثوم وتأثيرها على الظواهر النباتية للثوم

\author{
عفاف محمد صالح الروبي
}

$$
\text { بقسم بحوث افات الخضر و النباتات الطبية و العطرية و الزينة }
$$

أجريت هذه الدراسة في منطقة أبو قرقاص (محافظة المنيا) بمصر خلال موسم زر اعة الثوم

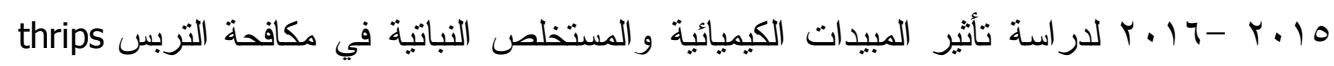
tabaci ((Thysanoptera: Thripidae)

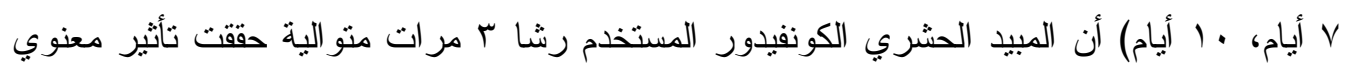

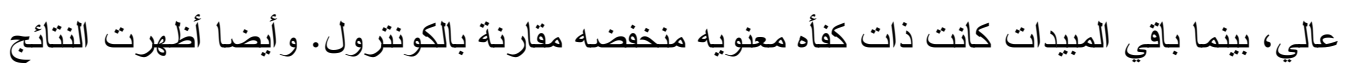

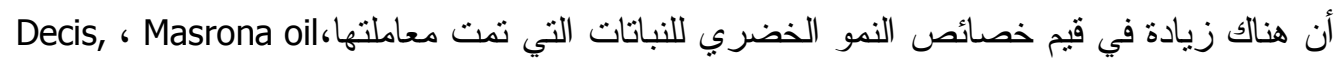

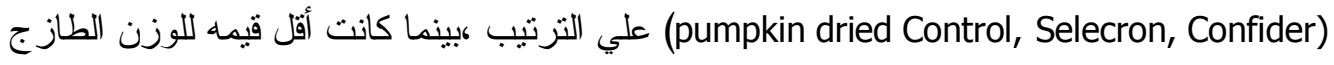
تم تسجيلها بمعظم المعاملات وكانت غبر معنويه. 